Jurnal HELPER, Vol 36 No 2 (2019) 17 - 26

Bimbingan dan Konseling Universitas PGRI Adi Buana Surabaya

ISSN: 02162938

\title{
EFEKTIFITAS KONSELING KELOMPOK MENGGUNAKAN PENDEKATAN \\ SELF MANAGEMENT UNTUK MEMPERBAIKI HUBUNGAN SOSIAL SISWA \\ KELAS XII TKJ B SMKS NURIS JEMBER
}

\author{
Trikayani \\ SMKS Nuris Jember \\ trikayanimoser@gmail.com \\ Dwi Noviarini \\ SMA Negeri 2 Pacitan \\ dwinoviarini1981@gmail.com
}

\begin{abstract}
Abstrak
Pada siklus 1 penelitian tindakan kelas ini, siswa yang menjadi obyek penelitian ada pada rangking 9 dengan pilihan 1,2,3 masing-masing 0 (Nol) di dukung dengan interprestasi pilihan dari teman-temannya yaitu dari jumlah 39 siswa yang tidak menyukai sejumlah 30 siswa, serta 2 orang siswa tidak menyatakan apa-apa kerena sedang sakit, 1 orang siswa ijin, dan yang tidak memberikan pernyataan apa-apa sejumlah 6 siswa. Sedangkan pada Siklus ke II Dilihat dari hasil analisa sosiometri yang ada maka posisi siswa yang menjadi obyek penelitian yaitu no kode 12 mendapat jumlah pilihan ke 2 dua orang dan pilihan ke 3 dua orang dengan jumlah total 4 pilihan yang sudah di berikan oleh teman-temannya. Dengan demikian sudah meningkat pada posisi rangking 5. Hasil layanan konsultasi dari guru bidang studi dan juga wali kelas bahwa kehadiran siswa yang menjadi Obyek penelitian sudah tidak lagi sering meninggalkan palajaran serta sudah namapak lebih baik dalam bergaul dengan teman-temannya di kelas, dari hasil konseling individu juga sudah ada alternatif yang sudah di laksanakan dan hasilnya sudah dirasakan banyak manfaatnya oleh siswa yang menjadi obyek penelitian.
\end{abstract}

Kata kunci: hubungan social, kenakalan siswa, metode sosiometri, layanan konseling dan konsultasi.

\begin{abstract}
In cycle 1 of this class action study, the student who became the object of the study was ranked 9th with a choice of 1,2,3 each 0 (Zero) supported by the choice of his friends, namely from the number of 39 students who disliked a total of 30 students, as well as 2 students who did not state anything about being sick, 1 permit student, and who did not give a statement of any number of 6 students. While in Cycle II judging by the results of sociometric analysis, the position of the student who became the object of the study namely no code 12 got the number of options to 2 two people and the choice to 3 two people with a total of 4 options that have been given by his friends. Thus it has increased at the position of rank 5 . The results of consulting services from teachers in the field of study and also parents that the presence of students who become research objects no longer often leave palajaran and already namapak better in associating with their friends in the classroom, from the results of individual
\end{abstract}


Jurnal HELPER, Vol 36 No 2 (2019) 17 - 26

Bimbingan dan Konseling Universitas PGRI Adi Buana Surabaya

ISSN: 02162938

counseling there is also an alternative that has been implemented and the results have been felt many benefits by students who become the object of research.

Keywords: social relationships, student delinquency, sociometric methods, counseling and consulting services.

\section{LATAR BELAKANG}

Hubungan sosial dipengaruhi oleh banyak faktor antara lain : keluarga dan pola asuh orang tua, teman sebaya, sekolah dan sistem pendidikan nasional. Kemampuan sosial remaja mendorong berkembangnya kompetensi sosial remaja. Kompetensi sosial merupakan keterampilan yang mengacu pada keterampilan sosial, emosional, kognitif serta keterampilan berperilaku yang membuat remaja akan berhasil dalam melakukan penyesuaian diri (Sarason, dalam Berman, 1992).Rahmat, 2003). Kompetensi sosial akan membantu dalam melakukan penyesuaian sosial dan membangun hubungan antar pribadi yang berkualitas.Kompetensi sosial merupakan hal yang dipelajari sedikit demi sedikit dari pengalaman seseorang dan mempunyai peranan penting dalam proses sosialisasi seseorang, karena kompetensi sosial merupakan indeks dan prediktor untuk penyesuaian diri yang sehat. Kompetensi sosial juga ikut menentukan proses penyesuaian sosial dan kualitas hubungan antar pribadi. Perkembangan kompetensi sosial dipengaruhi bimbingan di rumah (anggota keluarga), di sekolah, dan juga adanya kesempatan untuk menggunakan keterampilan yang dimiliki di masyarakat (Hurlock, 1992).

Kurikulum pendidikan nasional di Indonesia saat ini lebih banyak bobot pendidikannya yang diarahkan untuk merangsang perkembangan kognitif siswa dengan kurang diimbangi oleh stimulasi bagi perkembangan aspek sosial dan emosi. Sehingga, para siswa sibuk mengejar prestasi di sekolah dan akibatnya akan mengurangi waktu mereka bersosialisasi dengan masyarakat, sedangkan kompetensi sosial akan terbentuk dengan baik apabila individu terlibat langsung dalam interaksi sosial dengan orang lain/masyarakat secara bebas.

Hubungan sosial adalah Suatu kegiatan yang menghubungkan kepentingan antar individu, individu dengan kelompok atau antar kelompok yang secara langsung ataupun tidak langsung dapat menciptakan rasa saling pengertian dan kerja sama yang cukup tinggi, keakraban, keramahan, serta menunjang tinggi persatuan dan kesatuan bangsa.

Bimbingan dan konseling sebagai wadah di lingkungan sekolah yang memberikan pelayanan terhadap siswa dalam merancang 
Jurnal HELPER, Vol 36 No 2 (2019) 17 - 26

Bimbingan dan Konseling Universitas PGRI Adi Buana Surabaya

ISSN: 02162938

dan memfokuskan kebutuhan, minat, dan isu - isu yang berkaitan dengan perkembangan yang merupakan bagian penting dan integral dari keseluruhan program, harus mampu melakukan tindakan baik secara kuratif maupun prefentif dalam memecahkan persoalan yang berkaitan dengan permasalahan siswa. Permasalahan ini juga harus dipecahkan oleh para tenaga bimbingan dan konseling di lingkungan SMK Nuris Jember . Dari hasil identifikasi yang dilakukan persoalan kenakalan siswa banyak timbul ketika siswa melakukan hubungan sosial dengan teman-temannya dan pada saat menerima materi pelajaran.

Indikasi terjadinya kenakalan siswa adalah dari banyaknya pelanggaran yang dilakukan oleh siswa terhadap norma atau aturan yang telah ditetapkan. Menurut Syamsul Yusuf (2005) dalam perkembangannya siswa tidak terlepas dari pengaruh lingkungan baik fisik, psikis maupun sosial. Di samping itu juga, siswa memiliki sifat inherent. Hal ini mempengaruhi terhadap daya prediksi dalam mengidentifikasi perubahan yang terjadi pada siswa tersebut. Jika hal ini terjadi maka akan melahirkan diskontinuitas perkembangan perilaku siswa.

Sosiometri merupakan suatu metode untuk memperoleh data tentang hubungan sosial dalam suatu kelompok, yang berukuran kecil sampai sedang ( 10 - 50 orang), berdasarkan preferensi pribadi antara anggota-anggota kelompok (WS. Winkel, 1985). Sosiometri adalah alat yang tepat untuk mengumpulkan data mengenai hubungan-hubungan sosial dan tingkah laku sosial murid (I.Djumhur dan Muh. Surya, 1985). Sosiometri adalah alat untuk dapat melihat bagaimana hubungan sosial atau hubungan berteman seseorang ( Bimo Walgito, 1987 ).

Tes Sosiometri ada dua macam, yaitu :

1. Tes yang mengharuskan untuk memilih beberapa teman dalam kelompok sebagai pernyataan kesukaan untuk melakukan kegiatan tertentu (criterium ) bersamasama dengan teman-teman yang dipilih.

2. Tes yang mengharuskan menyatakan kesukaannya atau ketidaksukaannya terhadap temanteman dalam kelompok pada umumnya.

\section{Kegunaan Sosiometri}

Sosiometri dapat dipergunakan untuk :

1. Memperbaiki hubungan insani.

2. Menentukan kelompok kerja 
Jurnal HELPER, Vol 36 No 2 (2019) 17 - 26

Bimbingan dan Konseling Universitas PGRI Adi Buana Surabaya

ISSN: 02162938

3. Meneliti kemampuan memimpin seseorang individu dalam kelompok tertentu untuk suatu kegiatan tertentu.

4. Mengetahui bagaimana hubungan sosial / berteman seorang individu dengan individu lainnya.

5. Mencoba mengenali problem penyesuaian diri seorang individu dalam kelompok sosial tertentu.

6. Menemukan individu mana yang diterima / ditolak dalam kelompok social tertentu.

\section{Norma-norma Sosiometri}

Baik tidaknya hubungan sosial individu dengan individu lain dapat dilihat dari beberapa segi yaitu :

1. Frekwensi hubungan, yaitu sering tidaknya individu bergaul. makin sering individu bergaul, pada umumnya individu itu makin baik dalam segi hubungan sosialnya. Bagi individu yang mengisolir diri, di mana ia kurang bergaul, hal ini menunjukkan bahwa di dalam pergaulannya kurang baik.

2. Intensitas hubungan, yaitu intim tidaknya individu bergaul. Makin intim/mendalam seseorang dalam hubungan sosialnya dapat dinyatakan bahwa hubungan sosialnya makin baik. Teman intim merupakan teman akrab yang mempunyai intensitas hubungan yang mendalam.

3. Popularitas hubungan, yaitu banyak sedikitnya teman bergaul. Makin banyak teman di dalam pergaulan pada umumnya dapat dinyatakan makin baik dalam hubungan sosialnya. Faktor popularitas tersebut digunakan sebagai ukuran atau kriteria untuk melihat baik tidaknya seseorang dalam hubungan atau kontak sosialnya.

\section{Manfaat Sosiometri dalam Bimbingan.}

Dengan mempelajari data sosiometri seorang konselor dapat :

1. Menemukan murid mana yang ternyata mempunyai masalah penyesuaian diri dalam kelompoknya.

2. Membantu meningkatkan partisipasi sosial diantara muridmurid dengan penerimaan sosialnya.

3. Membantu meningkatkan pemahaman dan pengertian murid terhadap masalah pergaulan yang sedang dialami oleh individu tertentu. 
Jurnal HELPER, Vol 36 No 2 (2019) 17 - 26

Bimbingan dan Konseling Universitas PGRI Adi Buana Surabaya

ISSN: 02162938

4. Merencanakan program yang konstruktif untuk menciptakan iklim sosial yang lebih baik dan sekaligus membantu mengatasi masalah penyesuaian di kelas tertentu.

\section{Cara untuk menciptakan suasana / iklim} sosial yang baik :

a) Membentuk kelompok belajar / kelompok kerja .

b) Mempersatukan kelompok minoritas dalam klik di dalam satu kelas.

c) Menciptakan hubungan baik dan harmonis

d) Membangun perasaan berhasil dan berprestasi. Hendaknya ditanamkan rasa bahwa kalau kompak, akan berhasil baik.

Tahap-tahap Pelaksanaan Sosiometri

\section{Tahap Persiapan}

a) Menentukan kelompok siswa yang akan diselidiki.

b) Memberikan informasi atau keterangan tentang tujuan penyelenggaraan sosiometri.

c) Mempersiapkan angket sosiometri.

\section{Tahap Pelaksanaan}

a) Membagikan dan mengisi angket sosiometri.

b) Mengumpulkan kembali dan memeriksa apakah angket sudah diisi denganbenar

Tahap Pengolahan

a) Memeriksa hasil angket

b) Mengolah data sosiometri dengan cara menganalisa indeks, menyusun table tabulasi, membuat sosiogram.

\section{Bentuk-bentuk Sosiogram}

Sosiogram adalah diagram yang menunjukkan hubungan atau interaksi individu dalam sebuah kelompok, yang sekaligus dapat pula ditemukan pola hubungan sosial individu dengan individu lainnya. Sosiogram dapat dituangkan dalam bentuk sejumlah lingkaran (dari terkecil sampai terbesar) dan dalam bentuk lajur.

\section{Hal-hal yang dapat ditemukan dalam sosiogram :}

1. Apakah terdapat lebih banyak pilihan searah atau dua arah (saling memilih).

2. Apakah terdapat banyak pilihan antara siswa-siswa dan siswi-siswi atau kah hanya sedikit.

3. Apakah terdapat kelompok yang cenderung bersifat tertutup karena banyak terdapat saling memilih 
Jurnal HELPER, Vol 36 No 2 (2019) 17 - 26

Bimbingan dan Konseling Universitas PGRI Adi Buana Surabaya

ISSN: 02162938

sebagai pilihan pertama dan kedua (klik).

4. Apakah ada siswa yang tidak mendapat pilihan sama sekali (terisolir) atau hanya sedikit pilihan, apalagi pilihan ketiga saja (terabaikan).

5. Apakah ada siswa yang mendapat banyak pilihan, apalagi sebagai pilihan pertama.

6. Siswa ini dapat dianggap populer dalam kelompok seluruh kelompok teman, tetapi hanya dalam rangka kegiatan yang menjadi kriterium.

\section{Kelebihan dan kelemahan Sosiometri}

Kelebihan sosiometri :

a) mengetahui hubungan sosial antar siswa.

b) meningkatkan hubungan sosial antar siswa.

c) menempatkan siswa dalam kelompok yang sesuai.

d) menemukan siswa mana yang mempunyai masalah penyesuaian diri dengan kelompoknya.

e) membantu meningkatkan partisipasi sosial diantara siswa dengan penerimaan sosialnya. f) membantu meningkatkan pemahaman siswa dalam pergaulan yang sedang dialami.

g) membantu konselor dalam menciptakan iklim sosial yang lebih baik dengan menyesuaikan program yang konstruktif.

Kelemahan sosiometri.

a) sangat sulit dijamin kerahasiaannya, karena siswa cenderung saling mananyai pilihannya.

b) siswa memilih bukan atas dasar pertimbangan dengan siapa dia akan paling berhasil dalam melakukan pekerjaan, tetapi atas dasar rasa simpati dan antipati.

c) memerlukan waktu banyak / lama.

\section{Metodologi Penelitian}

Penelitian ini berjenis penelitian tindakan kelas. Rancangan pelaksanaan penelitian meliputi proses membuat percobaan ataupun pengamatan serta memilih pengukuran variabel, prosedur dan teknik sampling, instrumen, pengumpulan data, analisis data yang terkumpul, refleksi, dan pelaporan hasil penelitian.

Teknik pengumpulan dan teknik analisis data yang digunakan dalam penelitian ini adalah metode sosiometri. Data penelitian tindakan ini dapat 
Jurnal HELPER, Vol 36 No 2 (2019) 17 - 26

Bimbingan dan Konseling Universitas PGRI Adi Buana Surabaya

ISSN: 02162938

berbentuk catatan lapangan, catatan harian, transkrip komentar peserta penelitian, rekaman audio, rekaman video, foto dan rekaman/catatan lainnya.

\section{Hasil dan Pembahasan}

Penelitian tindakan bimbingan konseling ini dilaksanakan dikelas XII TKJ B SMKS Nuris Jember. Penelitian tindakan ini dilakukan dalam 2 siklus untuk menentukan bagaimana meningkatkan sikap/perilaku assertif siswa menggunakan konseling kelompok.

Penggunaan Teknik konseling kelompok dengan metode pendekatan Behaviorism Konseling kelompok teknik konseling Self Management dengan mengolah data melalui aplikasi sosiometri untuk memperbaiki hubungan sosial siswa XII TKJ B SMKS Nuris Jember ini diharapkan menguasai konsep dasarnya yaitu pengertian sosiometri, kegunaan sosiometri, cara mengerjakan instrument sosiometri. Karena pemahaman konsep dasar sangat penting untuk menunjang tercapainya penggunaan metode sosiometri ini.

Berdasarkan hasil analisa sosiometri yang dilakukan maka posisi siswa yang menjadi obyek penelitian ada pada rangking 9 dengan pilihan 1,2,3 masing-masing 0 (Nol) di dukung dengan interprestasi pilihan dari teman-temannya yaitu dari jumlah 39 siswa yang tidak menyukai sejumlah 30 siswa, serta 2 orang siswa tidak menyatakan apa-apa tidak masuk karena sakit, 1 orang siswa ijin , dan yang tidak memberikan pernyataan apa-apa sejumlah 6 siswa.

Sebagai refleksi dari siklus I, maka pada siklus II nantinya akan diadakan layanan bagaimana cara bergaul yang baik, dan juga akan diberikan layanan konseling individu kepada siswa yang menjadi obyek penelitian.

Berdasarkan hasil analisa sosiometri yang dilakukan maka posisi siswa yang menjadi obyek penelitian yaitu no kode 12 mendapat jumlah pilihan ke 2 dua orang dan pilihan ke 3 dua orang dengan jumlah total 4 pilihan yang sudah di berikan oleh teman-temannya. Dengan demikian sudah meningkat pada posisi rangking 5 .

Dari hasil observasi pelaksanaan tindakan siklus I diperoleh data 27 siswa yang aktif dan 9 siswa cukup aktif sedangkan 2 siswa Sudah berhenti dan 1 siswa Alpa. Atau dapat dikatakan dari 39 siswa, yang aktif mengikuti layanan adalah 92,30 \%. Sedangkan pada siklus II sudah mengalami peningkatan Dari hasil observasi pelaksanaan tindakan siklus II diperoleh data 35 siswa yang aktif dan 2 siswa cukup aktif sedangkan 2 siswa Sudah berhenti 
Jurnal HELPER, Vol 36 No 2 (2019) 17 - 26

Bimbingan dan Konseling Universitas PGRI Adi Buana Surabaya

ISSN: 02162938

Atau dapat dikatakan dari 39 siswa, yang aktif mengikuti layanan adalah 94,59 \%.

Dilihat dari hasi analisa sosiometri pada siklus I yang ada, maka posisi siswa yang menjadi obyek penelitian ada pada rangking 9 dengan pilihan 1,2,3 masingmasing $0 \quad$ (Nol) di dukung dengan interprestasi pilihan dari teman-temannya yaitu dari jumlah 39 siswa yang tidak menyukai sejumlah 30 siswa, serta 2 orang siswa tidak menyatakan apa-apa kerena sedang sakit, 1 orang siswa ijin, dan yang tidak memberikan pernyataan apa-apa sejumlah 6 siswa.

Sedangkan pada Siklus ke II Dilihat dari hasil analisa sosiometri yang ada maka posisi siswa yang menjadi obyek penelitian yaitu no kode 12 mendapat jumlah pilihan ke 2 dua orang dan pilihan ke 3 dua orang dengan jumlah total 4 pilihan yang sudah di berikan oleh teman-temannya. Dengan demikian sudah meningkat pada posisi rangking 5 .

Dilihat dari hasil sosiogram siklus I obyek penelitian adalah siswa dengan no kode 12 , dia berada di ring 9 dengan tanpa ada teman-teman yang memilih dia walaupun dia sendiri telah memilih no kade 9 sebagai pilihan Pertama (1) Kade 13 sebagai pilihan Ke Dua (2) dan kode 3 sebagai pilihan ke tiga (3) sedangkan pada siklus II dapat dilihat dari hasil Sosiogram siswa yang menjadi Obyek penelitian dengan no kode 12 sudah menduduki posisi di ring ke 5 dengan empat orang temanya yang memilih yaitu no kode 2 dengan menempatkan siswa yang menjadi obyek penelitian pada pilihan ke 3 , kode 4 dengan menempatkan siswa yang menjadi obyek penelitian pada pilihan ke 2, kode 26 dengan menempatkan siswa yang menjadi obyek penelitian pada pilihan ke 2 dan kode 33 dengan menempatkan siswa yang menjadi obyek penelitian pada pilihan ke 3 namun untuk siswa yang menjadi Obyek penelitian sendiri masih memilih no kade 9 sebagai pilihan Pertama (1) Kade 13 sebagai pilihan Ke Dua (2) dan kode 3 sebagai pilihan ke tiga (3)

Selain itu juga dari hasil layanan konsultasi dari guru bidang studi dan juga wali kelas bahwa kehadiran siswa yang menjadi Obyek penelitian sudah tidak lagi sering meninggalkan palajaran serta sudah namapak lebih baik dalam bergaul dengan teman-temannya di kelas, dari hasil konseling individu juga sudah ada alternatif yang sudah di laksanakan dan hasilnya sudah dirasakan banyak manfaatnya oleh siswa yang menjadi obyek penelitian.

\section{Simpulan}

Sesuai dengan rumusan masalah dan tujuan penelitian maka secara umum dapat disimpulkan bahwa aktivitas siswa dalam mengikuti layanan Bimbingan Konseling 
Jurnal HELPER, Vol 36 No 2 (2019) 17 - 26

Bimbingan dan Konseling Universitas PGRI Adi Buana Surabaya

ISSN: 02162938

sudah meningkat secara khusus dapat di simpulkan bahwa penggunaan metode sosiometri untuk memperbaiki hubungan sosial siswa Di kelas XII TKJ B SMKS Nuris Jember khususnya bagi siswa yang menjadi obyek penelitian sebagai berikut :

1. Dari hasil analisa sosiometri dan juga Sosiogram siklus I di peroleh bahwa siswa yang menjadi obyek penelitian tergolong siswa yang terisolir

2. Setelah diberikan tindakan melalui metode sosiometri sudah mengalami peningkatan sampai pada akhirnya siswa yang menjadi obyek penelitian bisa menduduki ring ke 5 yang sebelumnya menduduki rig ke 9.

3. Metode sosiometri bisa digunakan bersama-sama dengan metode yang lain dalam hal ini metode konsultasi dan konseling individu.

\section{Saran}

1. Untuk rekan-rekan sesama guru BK sedapatnya menggunakan metode sosiometri ini untuk membantu menangani masalah sosial yang di hadapi Siswa.

2. Penelitian ini masih terbatas pada penggunaan metode sosiometri, konseling individu, dan juga konsultasi tidak menutup kemungkinan untuk peneliti lebih lanjut bisa di gunakan bersamasama dengan metode-metode yang lain.

\section{Daftar Pustaka}

Ali dan Asrori. 2005. Psikologi Remaja Perkembangan Peserta Didik. Jakarta: PT Bumi Aksara.

Ali, Mohamad. 1984. Penelitian Kependidikan Prosedur dan Strategi. Bandung: Angkasa

Arikunto, Suharsimi. 2006. Prosedur Penelitian Suatu Pendekatan Prakteik. Jakarta: Rineka Cipta. Azwar, Saifuddin. 2005. Penyusunan Skala Psikologi. Yogyakarta: Pustaka Pelajar.

Corey, Gerald. (2007). Teori dan Praktek Konseling dan Psikoterapi. Refika Aditama. Bandung.

Dayakisni dan Hudaniah. 2009. Psikologi Sosial. Malang: UMM Press

Desmita. 2009. Psikologi Perkembangan. Bandung: PT Remaja Rosdakarya

Gerungan. 2002. Psikologi Sosial. Bandung: Refika Aditama

Gunarso, Singgih. 2007. Psikologi Perkembangan. Jakarta : Gunung Muria. 
Jurnal HELPER, Vol 36 No 2 (2019) 17 - 26

Bimbingan dan Konseling Universitas PGRI Adi Buana Surabaya

ISSN: 02162938

Hadi, Sutrisno. 2000. Statistik Jilid II. Prayitno. (1998). Konseling Panca Yogyakarta: ANDI.

Waskita, PSBK. FIP IKIP Padang.

Hariyadi, Sugeng, dkk. 1995. Taufik. 2002. Model-model Konseling.

Perkembangan Peserta didik. Semarang: $\quad$ Padang: BK FIP UNP.

IKIP Semarang Press.

Jones, Richard Nelson. (2011). Teori dan

WS. Winkel \& M.M Sri Hastuti (2005),

Praktik Konseling dan Terapi. Pustaka Bimbingan dan Konseling di Institusi Pelajar. Yogyakarta.

Komalasari, Gantina., dkk. (2011) Teori dan Teknik Konseling. PT Indeks, Jakarta. Lesmana, Jeanette Murad (2005). Dasar-

Dasar Konseling. Universitas Indonesia. Jakarta. 